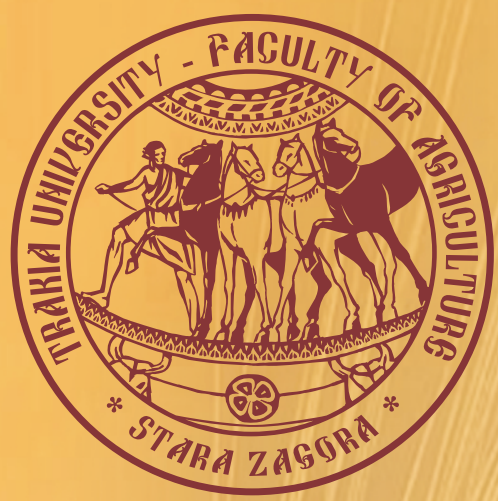

ISSN $1313-8820$ (print)

ISSN 1314 - 412X (online)

Volume 9 , Number 4

December 2017

\title{
AGRICULTURAL
}

\section{SCIENCE AND TECHNOLOGY}

\section{7}

An International Journal Published by Faculty of Agriculture, Trakia University, Stara Zagora, Bulgaria 


\section{Editor-in-Chief}

Georgi Petkov

Faculty of Agriculture

Trakia University, Stara Zagora

Bulgaria

E-mail: gpetkov@af.uni.sz.bg

\section{Co-Editor-in-Chief}

Dimitar Panayotov

Faculty of Agriculture

Trakia University, Stara Zagora

Bulgaria

\section{Editors and Sections}

\section{Genetics and Breeding}

Tsanko Yablanski (Bulgaria)

Atanas Atanasov (Bulgaria)

Svetlana Georgieva (Bulgaria)

Nikolay Tsenov (Bulgaria)

Max Rothschild (USA)

Ihsan Soysal (Turkey)

Horia Grosu (Romania)

Stoicho Metodiev (Bulgaria)

Bojin Bojinov (Bulgaria)

\section{Nutrition and Physiology}

Nikolai Todorov (Bulgaria)

Peter Surai (UK)

Ivan Varlyakov (Bulgaria)

George Zervas (Greece)

Vasil Pirgozliev (UK)

\section{Production Systems}

Radoslav Slavov (Bulgaria)

Dimitar Pavlov (Bulgaria)

Bogdan Szostak (Poland)

Banko Banev (Bulgaria)

Georgy Zhelyazkov (Bulgaria)

\section{Agriculture and Environment}

Martin Banov (Bulgaria)

Peter Cornish (Australia)

Vladislav Popov (Bulgaria)

Tarek Moussa (Egypt)

\section{Product Quality and Safety}

Stefan Denev (Bulgaria)

Vasil Atanasov (Bulgaria)

Roumiana Tsenkova (Japan)

\section{English Editor}

Yanka Ivanova (Bulgaria)
Scope and policy of the journal Agricultural Science and Technology /AST/ - an International Scientific Journal of Agricultural and Technology Sciences is published in English in one volume of 4 issues per year, as a printed journal and in electronic form. The policy of the journal is to publish original papers, reviews and short communications covering the aspects of agriculture related with life sciences and modern technologies. It will offer opportunities to address the global needs relating to food and environment, health, exploit the technology to provide innovative products and sustainable development. Papers will be considered in aspects of both fundamental and applied science in the areas of Genetics and Breeding, Nutrition and Physiology, Production Systems, Agriculture and Environment and Product Quality and Safety. Other categories closely related to the above topics could be considered by the editors. The detailed information of the journal is available at the website. Proceedings of scientific meetings and conference reports will be considered for special issues.

\section{Submission of Manuscripts}

There are no submission / handling / publication charges.

All manuscripts written in English should be submitted as MS-Word file attachments via e-mail to editoffice@agriscitech.eu. Manuscripts must be prepared strictly in accordance with the detailed instructions for authors at the website

www.agriscitech.eu and the instructions on the last page of the journal. For each manuscript the signatures of all authors are needed confirming their consent to publish it and to nominate on author for correspondence.

They have to be presented by a submission letter signed by all authors. The form of the submission letter is available upon from request from the Technical Assistance or could be downloaded from the website of the journal. Manuscripts submitted to this journal are considered if they have submitted only to it, they have not been published already, nor are they under consideration for publication in press elsewhere. All manuscripts are subject to editorial review and the editors reserve the right to improve style and return the paper for rewriting to the authors, if necessary. The editorial board reserves rights to reject manuscripts based on priorities and space availability in the journal.

The journal is committed to respect high standards of ethics in the editing and reviewing process and malpractice statement. Commitments of authors related to authorship are also very important for a high standard of ethics and publishing. We follow closely the Committee on Publication Ethics (COPE), http://publicationethics.org/resources/guid elines

The articles appearing in this journal are indexed and abstracted in: DOI, EBSCO Publishing Inc., AGRIS (FAO) and DOAJ.

The journal is accepted to be indexed with the support of a project № BG051PO0013.3.05-0001 "Science and business" financed by Operational Programme "Human Resources Development" of EU. The title has been suggested to be included in SCOPUS (Elsevier) and Electronic Journals Submission Form (Thomson Reuters).

The journal is freely available without charge to the user or his/her institution. Users can read, download, copy, distribute, print, search, or link to the full texts of the articles, or use them for any other lawful purpose, without asking prior permission from the publisher or the author.

This issue is printed with the financial support by Contract No DNP 0521/20.12.2016, financed from Fund 'Scientific Research' grant Bulgarian scientific Periodicals.

\section{Address of Editorial office:}

Agricultural Science and Technology Faculty of Agriculture, Trakia University

Student's campus, 6000 Stara Zagora

Bulgaria

Telephone: +35942699330 $+35942699446$

www.agriscitech.eu

Technical Assistance:

Nely Tsvetanova

Telephone: +359 42699446

E-mail:editoffice@agriscitech.eu 


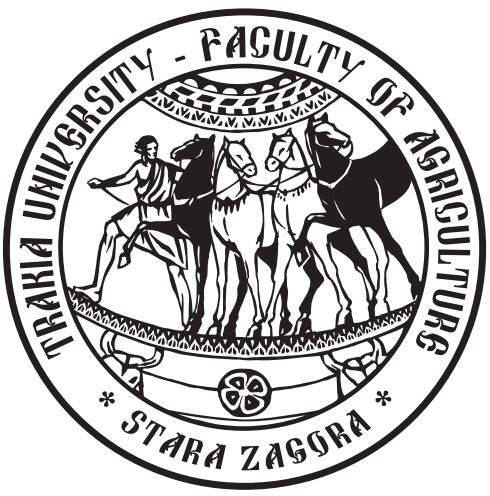

AGRICULTURAL

SCIENCE AND TECHNOLOGY

\section{7}

An International Journal Published by Faculty of Agriculture,

Trakia University, Stara Zagora, Bulgaria 


\title{
Heavy metals in organs of gudgeon (Gobio gobio L.) from Vardar River, R. Macedonia
}

\author{
R. Nastova*, V. Kostov, I. Ushlinovska \\ Institute of Animal Science, "Ss. Cyril and Methodius" University, Blvd. llinden 92 A, 1000 Skopje, Republic of Macedonia
}

(Manuscript received 4 August 2017; accepted for publication 13 November 2017)

\begin{abstract}
Ecotoxicological examinations based on seven heavy metals ( $\mathrm{Fe}, \mathrm{Cu}, \mathrm{Zn}, \mathrm{Mn}, \mathrm{Cd}, \mathrm{Pb}$ and $\mathrm{Cr}$ ) concentrations in organs of gudgeon (Gobio gobio $\mathrm{L}$.) caught by 14 monitoring points at Vardar River in Republic of Macedonia were performed. The organ's samples elements were read-out on AAS in flame and graphite cuvette. Significant increase of $\mathrm{Pb}$ and $\mathrm{Cd}$ contents in liver, gills and gonads of fish sampled downstream Skopje and the town of Veles was found. It should be pointed out that at times Cd concentrations in muscles were as high as $0.518 \mathrm{mg} / \mathrm{kg}$ which is significantly over the maximally allowed concentrations forhumannutrition.
\end{abstract}

Keywords: Gobio gobio L., organs, heavy metals concentration

\section{Introduction}

Freshwater fish fauna biodiversity can be viewed through the vast variety of the wildlife on the Balkan Peninsula. Wildlife communities in this area have constantly been exposed to various geomorphological, climatic and anthropogenic influences. This fact has preconditioned their biodiversity. For preservation of fish species on an international level, it is a must to get insights into all the changes in the aquatic communities in the Republic of Macedonia and on the whole territory of the Balkan Peninsula.

Vardar is the biggest Macedonian river, where all the waterflows in the country flow in, except for the rivers Drim and Strumica. The first data on the river Vardar ichthyofauna was reported by Steindachner (1892) who described Leucos macedonicus from the Vardar River basin by the samples from Doiran Lake. Doflein (1921), in his work covering the results of the Macedonian commission surveys, quotes 11 fish species in Vardar River.

Vardar River as part of the Balkan hydroecosystems, isn't sufficiently researched from the aspect of ichthyodiversity and ecotoxicology at the ichthyofauna level. It ought to be especially mentioned that on the area of the Western Balkans many endemic species have survived, being among the eldest in Europe. Since these species are endangered, and the ichthyofauna in general, special attention to such types of research was paid in the works of Antipa (1909), Taler (1954), Drecun (1956, 1957, 1962); Janković (1965, 1977, 1978, 1979, 1980), Janković et al. (1987, 1994), Ivanović (1973), Hacker (1983), Knežević and Marić (1987), Maletin et al. (1990, 1994) and Pujin et al. (1996).

Their own contributions to the insights about the fishes in Vardar River, gave Karaman (1962), Petrovski et al. (1970) and Dimovski and Grupče (1971, 1971a, 1971b, 1972). According to their investigations, the river is inhabited by approximately 24 fish species.

The ecosystem's biodiversity includes the variety of biocenoses, habitats and ecological processes, upon which an ecosystem's funcionality can be defined (Đukić et al., 1993, 1994 1996, 1997, 1998; Maletin et al., 1994, 1997, 1998; Maletin and

*e-mail: rodne_nastova@yahoo.com
Đukić, 1998). Fish fauna diversity in the upper flow of the Vardar River is still well preserved, though certain sectors of this hydroecosystem are subject to drastic changes, which presents a serious threat for the ichthyofauna structure. Some fish species in that river (Leuciscus cephalus L., Barbus barbus L., Barbus meridionalis Risso, Vimba vimba L.) are reliable bioindicators of the respective ecological conditions and their changes occurred within a shorter or longer period of time (Nastova, 2004; Nastova-Giorgioska etal., 2006).

Ichthyofauna is a part of the aquatic wildlife community and is an important component in the food chain. It has active participation in the process of self-filtration of the hydroecosystems (Đukić et al., 1991, 1992; Maletin et al., 1991, 1992, 1995; Jordanovski and Naumovski, 1998; Talevska, 1998; Talevski and Spirkovski, 1998).

Pollution of waterflows with bio-non-degradable substances is a complex problem the solving of which requires a comprehensive approach. In the last decade, special attention has been paid to studying the load with toxic and hazardous substances, one of which are the micropollutants. Biological parameters are some of the most reliable indicators for estimating the state of a hydroecosystem, for they are not only a reflection of the current quality of the environment, but also give a picture for a long period of time. Fish population is of exceptional ecological and economic importance. It is a certain fact that fish are members of the highest trophic levels of biocenosis and they are a reflection of the hydroecosystem metabolism. From the aspect of the quality of nutrition and protection of human health, a very important factor is the content of hazardous and toxic substances in the muscle tissues of fishes (Foerstner and Wittman, 1981; Petrović et al., 1987; Wachs, 1990, 1991; Yevtushenko and Sytnik, 1989; Pujin et al., 1990; Sytnik et al., 1991; Salanki et al., 1992; Maletin et al., 1992, 1996; Janković and Jovičić, 1994; Đukić et al., 1998; Teodorović, 1999).

According to the OECD recommendation of 1991 (State of the Environment, 1990 - quote: Jorgensen et al., 1994), heavy metal concentrations in fish tissues can be a useful indicator for the load of these pollutants in water. The implementation of the ichthyofauna in the biomonitoring process and the analyses of the trends in the hydroecosystems are also recommended by HELCOM (Helsinki 
Commission) and OSPARCOM (Oslo and Paris Commission, 1990 - quote: Jorgensen et al., 1994).

Heavy metals have negative impact on the metabolism, physiology and dynamics of fish population through the food chain in the water and may threaten human health. In this process, the most relevant for human health are the concentrations of heavy metals in the muscles, since they are used for nutrition of people. Chevreuil et al. (1995) think that, despite the high toxicity and the persistence of organic and metallic micropollutants, investigations and data about the levels of contamination of continental aquatic systems are relatively few. Determination of the contents of pollutant residuals in the tissues of aquatic organisms is used, but it hasn't been implemented widely yet within systematic biomonitoring of freshwater ecosystems, nor there are standardized methods and types for this kind of monitoring of pollution. The aforementioned authors think that fish, because of their ecological characteristics (lifetime, way of nutrition, distribution) and economic effects, consist of a group which may be a reliable parameter in monitoring aquatic ecosystems.

Gudgeon (Gobio gobio L.), a fish which inhabits the Vardar River in the Republic of Macedonia has not been studied enough, including the accumulation of heavy metals in the tissues and organs. Karaman (1924) found gudgeon in the smaller confluents of the Vardar River near Skopje, and later (1931) he denoted gudgeon as a frequent fish species in the running waters of Skopje round valley. It is important to know whether this fish can be used as a bioindicator for assessing the ecological status of different river zones.

Gudgeon lives in small shoals at the bottom, where it finds food. It inhabits clean waters, with good flow and sandy to clay bottom, as well as in low-flux river branches. It also lives in clean lakes. The fish spawns in portions, from May to August, on sandy or gravel substrates. It matures sexually between the second and fourth year of life, when its length is 6 to $8 \mathrm{~cm}$. The fertility is 1.000 to 3.000 eggs, which have a diameter of around $2 \mathrm{~mm}$. The hard roe is sticky, and the development of the embryos takes 7 to 10 days. The larvae and the brood feed with tiny invertebrates, while the adult units feed with larvae of chironomids, tiny molluscs, roe from other fishes, and vegetation. Gudgeon can grow up to $22 \mathrm{~cm}$ in length and $80 \mathrm{~g}$ in weight (Naumovski, 1995)

The aim of the study was to make an ecotoxicological examinations of the Vardar River in the Republic of Macedonia based on seven heavy metals ( $\mathrm{Fe}, \mathrm{Cu}, \mathrm{Zn}, \mathrm{Mn}, \mathrm{Cd}, \mathrm{Pb}$ and $\mathrm{Cr}$ ) concentrations in gudgeon's (Gobio gobio L.) organs.

\section{Material and methods}

The object of the study was gudgeon (Gobio gobio L.) from the Vardar River, Republic of Macedonia during the period from 2014 to 2015. For the purpose of the investigation the species Gobio gobio L. (gudgeon) was captured in 14 of all the 16 locations (Monitoring points - MPs) of the Vardar River (Table 1, Figure 1). Samples from the species ( $n=376$ ) were analyzed from each monitoring point. Five specimens of gudgeon were analyzed from each monitoring point $(n=5)$.

Samples of muscles, gills, liver and gonads from gudgeon (Gobio gobio L.) had been prepared using standard procedure - by drying at $105^{\circ} \mathrm{C}$ and dissolving in a mixture of three acids: $\mathrm{HNO}_{3}$, $\mathrm{H}_{2} \mathrm{SO}_{4}$ and $\mathrm{HClO}_{4}$ (Allen et al., 1974). The samples were read out on AAS in flame and graphite cuvette. The contents of 7 metals were
Table 1. Monitoring points at the Vardar River and number of captured specimens of Gobio gobio Linnaeus 1758

\begin{tabular}{lcc}
\hline \hline Locations & Number of captured specimens & $\%$ \\
\hline Volkovija & 52 & 13.83 \\
Siricino & 45 & 11.97 \\
Radusa & 54 & 14.36 \\
Skopje & 45 & 11.97 \\
Aerodrom & 15 & 3.99 \\
Trubarevo & 25 & 6.65 \\
Taor I & 18 & 4.79 \\
Basino Selo & 25 & 6.65 \\
HIV & 15 & 3.99 \\
Nogaevci & 40 & 10.64 \\
Pepeliste & 21 & 5.59 \\
Demir Kapija & 9 & 2.39 \\
Miravci & 5 & 1.33 \\
Gevgelija & 7 & 1.86 \\
Total & 376 & 100.00 \\
\hline \hline
\end{tabular}

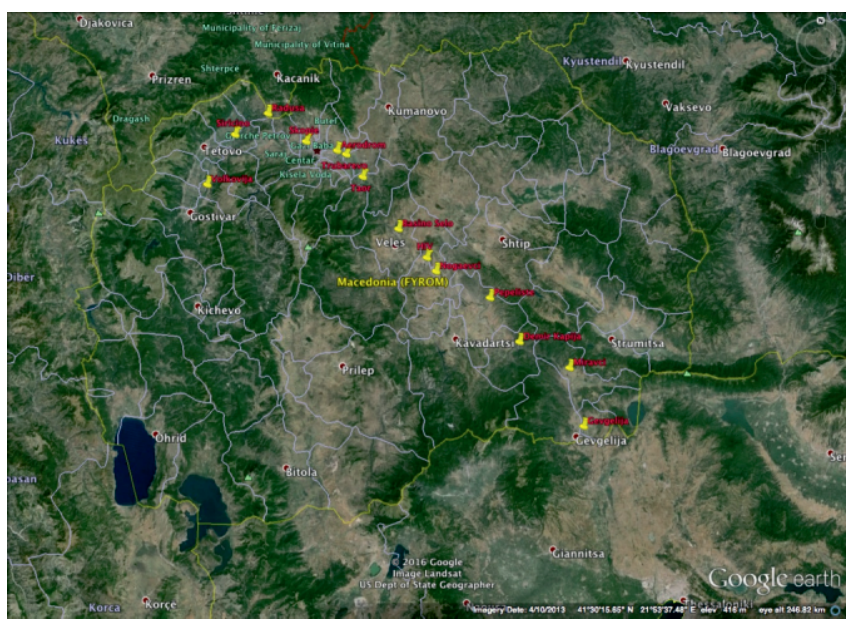

Figure 1. Map of Vardar River valley with monitoring points

analysed, namely: $\mathrm{Zn}, \mathrm{Mn}, \mathrm{Fe}, \mathrm{Cu}, \mathrm{Cr}, \mathrm{Cd}, \mathrm{Pb}$. The concentrations of metals in fish tissues and organs are expressed in $\mathrm{mg} / \mathrm{kg}$ fresh mass, for compatibility with the legal regulations regarding micropollutant contents in fishes.

A complete statistical processing was performed using standard software packages: Microsoft Excel and Statistics. For establishing the distribution of heavy metals and for comparing two different locations based on the contents of metals, standard statistical methods were used:

- all the results presented are given with the arithmetic mean value $(x)$ and standard deviation (SD).

- the significance of the difference between the concentrations of accumulated metals in individual tissues and the analysis of the variance was performed using one-way ANOVA test (Kruskal-Wallis).

- the significance of the difference between both locations was established using one-way ANOVA (Kruskal-Wallis) test, and was checked using an independent t-test.

- in all the parametric tests, a significance of the difference was allocated to $p \leq 0.05$.

- for the graphic imagery a Box-Whisker's diagram was 
implemented, where, beside the arithmetic mean values, variability is also presented.

\section{Results and discussion}

The results obtained for the studied heavy metals concentrations in tissues and organs of the gudgeon (Gobio gobio L.) from different MPs at the Vardar River revealed the following picture:

Fe. Fe concentration values in the organs of Gobio gobio L. units are shown in Figures 2 and 3 . There the arithmetic mean values of the samples, the corresponding standard deviations, coefficients of variations and the results of t-test and F-test are given. The maximum value for Fe concentration in gudgeon's liver in the comparison between samples from the upper and the lower parts of the Vardar River, is $315 \mathrm{mg} / \mathrm{kg}$. From the Box-Whiskers's diagram it can be seen that Fe is mostly accumulated in liver. According to ttest, the concentrations measured in liver are very significant ($\left.3.98^{* *}\right)$.

The values for Fe concentrations in muscles from the upper and the lower part of the Vardar, are 2.28*. In Figure 3 it can be seen that

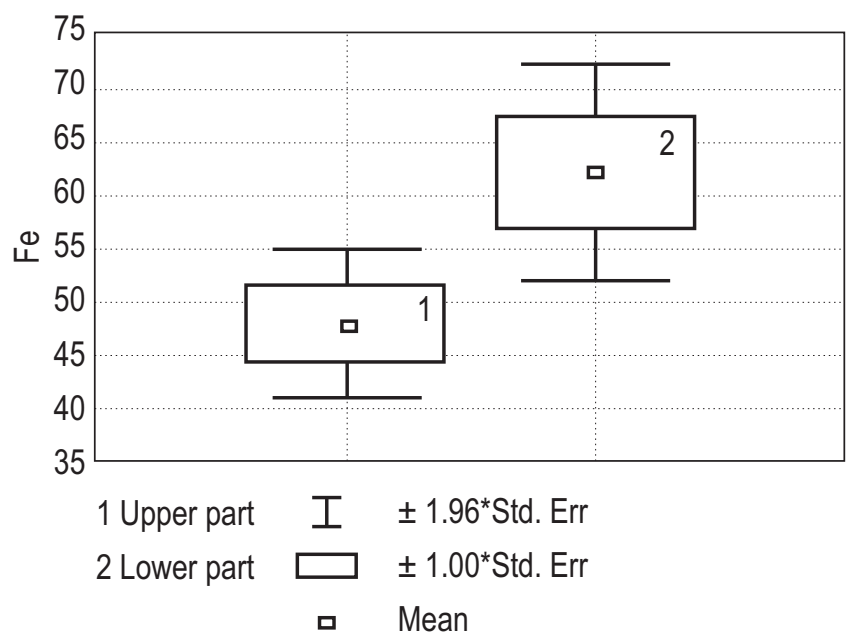

Figure 2. Fe concentrations in liver of Gobio gobio L. from the upper and the lower part of the Vardar River

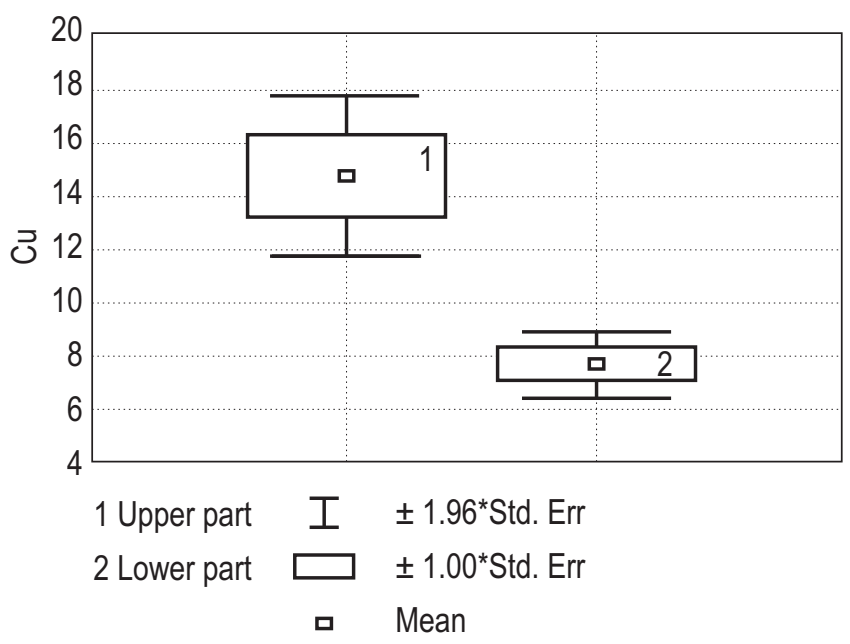

Figure 4. $\mathrm{Cu}$ concentrations in muscles of Gobio gobio L. from the upper and the lower part of the Vardar River there is an overlap of the intervals, and the difference between the environments surveyed is at the threshold of the significance. By comparison of Fe concentrations in gills and gonads of dudgeon from the upper and the lower part of the river, differences have been found, which are not statistically significant.

$\mathrm{Cu}$. In Figure 4 it can be seen that, according to the analysed results, there is a difference in $\mathrm{Cu}$ concentrations in gudgeon's organs between the units (MPs) from the upper and the lower part of the river. So, the highest maximum value for $\mathrm{Cu}$ in muscles is $10.5 \mathrm{mg} / \mathrm{kg}$. According to the t-test, the highest Cu concentrations in muscles are $-4.21^{* *}$, and the differences are statistically very significant. In gonads, liver and gills, no statistically significant differences in Cu concentrations have been measured.

$\mathrm{Mn}$. The data from the monitoring of Mn concentrations in gudgeon samples from the upper and the lower part of the river are shown in Figure 5 . The statistically processed data show that concentration of manganese is the highest in liver, where the difference is statistically very significant $\left(-5.31^{* *}\right)$. In all the other organs there is no statistically significant difference in $\mathrm{Mn}$ concentrations for the units from both parts of the river.

$\mathrm{Pb}$. The high load with $\mathrm{Pb}$ of Vardar's water downstream the town of Veles, is another indicator that in this part of the river there is

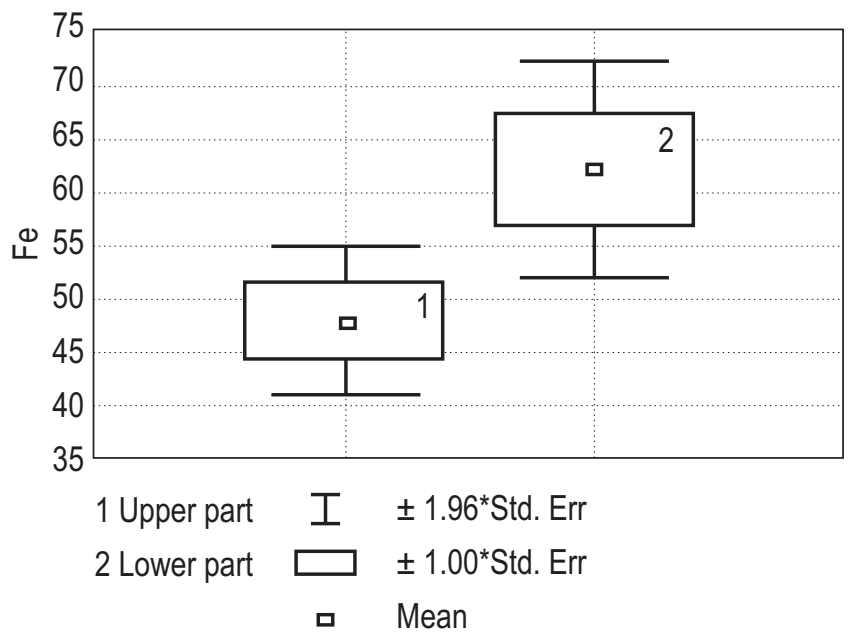

Figure 3. Fe concentrations in muscles of Gobio gobio L. from the upper and the lower part of the Vardar River

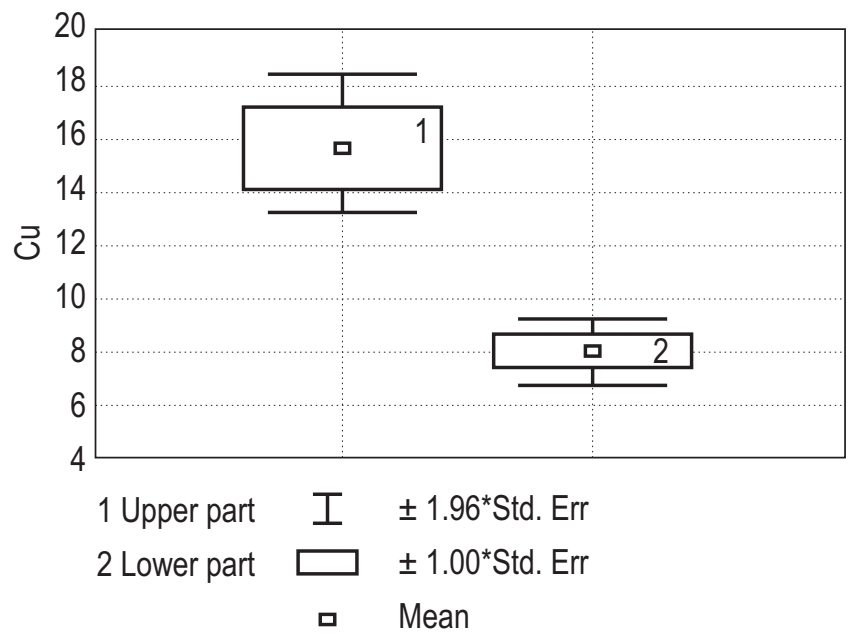

Figure 5. Mn concentrations in liver of Gobio gobio L. from the upper and the lower part of the Vardar River 


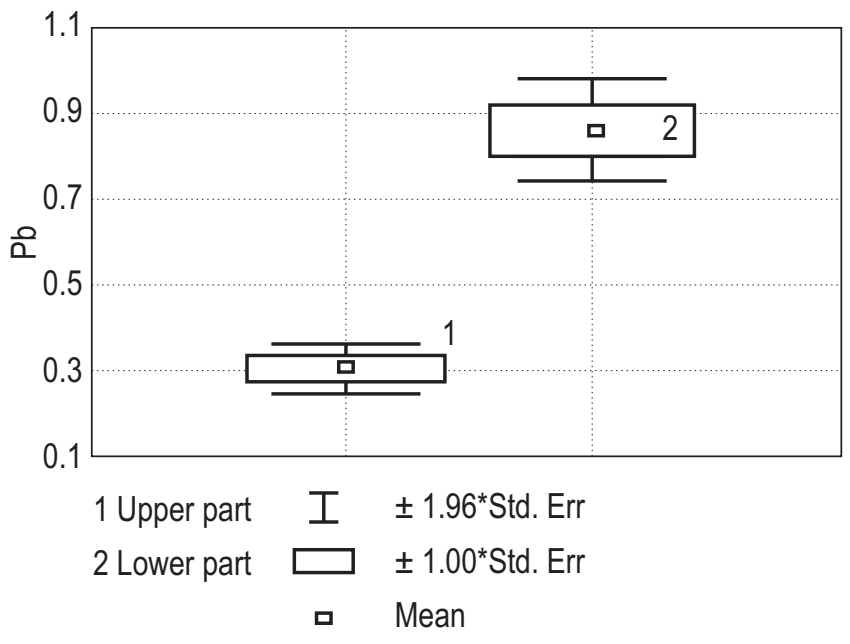

Figure 6. $\mathrm{Pb}$ concentrations in liver of Gobio gobio L. from the upper and the lower part of the Vardar River

presence of heavy metals. Effluents flow into this part of the Vardar River, originating from the industrial plants in the town. The highest value of the difference between $\mathrm{Pb}$ concentrations from the upper and the lower part of the Vardar River, is $1.18 \mathrm{mg} / \mathrm{kg}$. From Figure 6 it can be seen that $\mathrm{Pb}$ concentration is the highest in gudgeon's liver, and amounts to $8.29^{* *}$. In the diagram it can be seen that there is no overlap of intervals, meaning that the difference between the river parts surveyed is very significant. A statistically very significant $\mathrm{Pb}$ concentration is present in the gills, too $\left(5.08^{* *}\right)$. This is clearly shown in Figure 7.

$\mathrm{Cd}$. The analysis of $\mathrm{Cd}$ concentrations in particular tissues of gudgeon samples from the upper and the lower part of the Vardar River, is shown in Figures 8, 9, 10 and 11. The highest $\mathrm{Cd}$ concentrations in gudgeon's liver from the lower part of the Vardar were $1.87 \mathrm{mg} / \mathrm{kg}$ (Figure 8). By comparison of Cd concentrations in the samples from the upper and the lower part of the river using ttest, it was found that $\mathrm{Cd}$ is mostly accumulated in liver $\left(26.59^{* *}\right)$. The difference is very significant. In gudgeon units from the lower part, maximum $\mathrm{Cd}$ concentration in gills was $1.56 \mathrm{mg} / \mathrm{kg}$, and $0.16 \mathrm{mg} / \mathrm{kg}$ in gonads (Figures 9 and 10). The values from the t-test for $\mathrm{Cd}$ concentrations in gills were $7.40^{* *}$ in gills and $4.45^{* *}$ in gonads. This means that there is a very significant difference

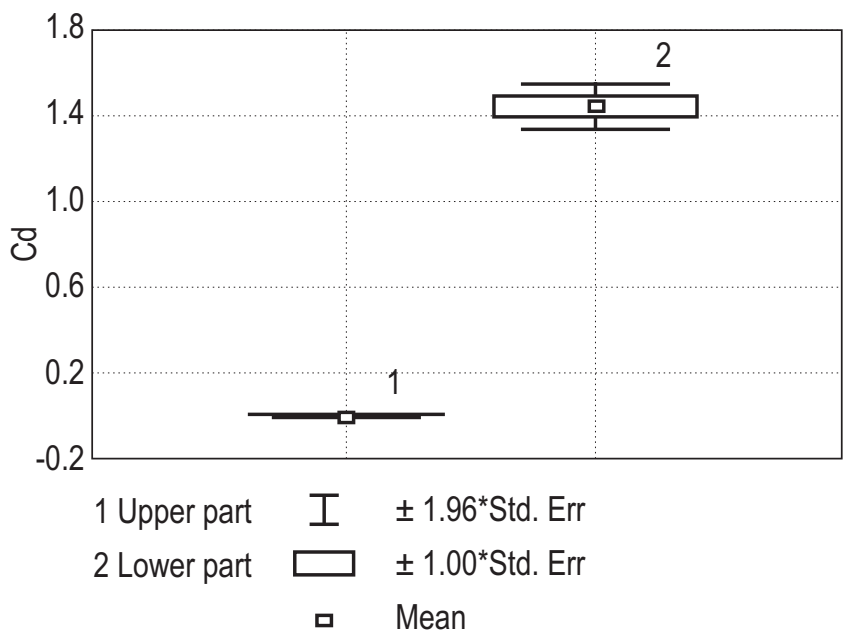

Figure 8. Cd concentrations in liver of Gobio gobio L. from the upper and the lower part of the Vardar River

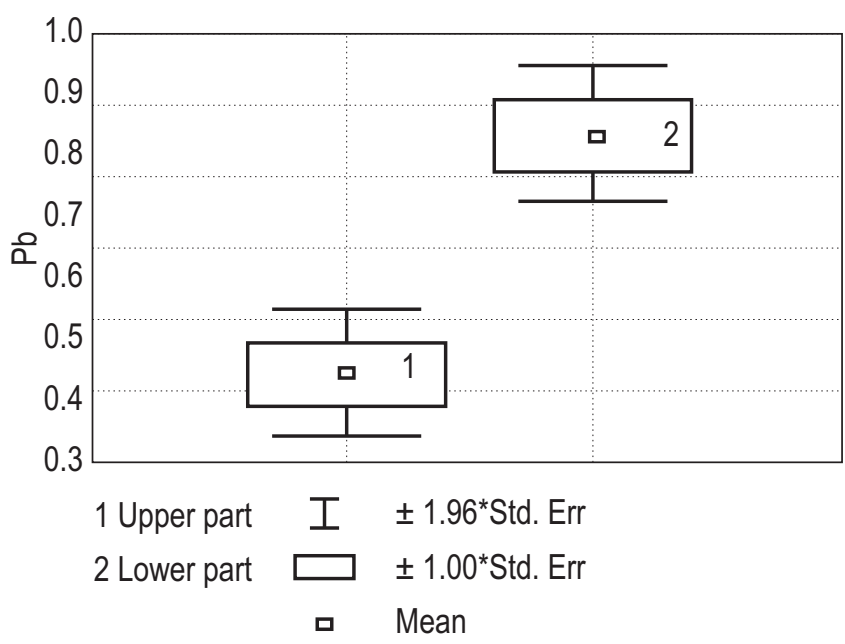

Figure 7. $\mathrm{Pb}$ concentrations in gills of Gobio gobio L. from the upper and the lower part of the Vardar River

between the amounts of accumulated $\mathrm{Cd}$ in the gills and the gonads of gudgeon units from both parts (Figure 10). However, by comparison of $\mathrm{Cd}$ concentrations in muscles which are greatly less than those in liver, gonads and gills, values have been obtained indicating that the differences in this respect are not statistically proven (Figure 11).

Cr. In Figures 12, 13, 14 and 15, the intervals of Box-Whisker's diagrams are far from one another. This means that the differences between $\mathrm{Cr}$ concentrations in liver (Figure 12), muscles (Figure 13) and gonads (Figure 14) of gudgeons from the upper and the lower part of the Vardar River are statistically very significant. Only in Figure 15 there is some overlap of the intervals, and this is for concentrations of chromium in gills. Independent t-test between the samples from both parts has shown that the values for $\mathrm{Cr}$ in the gills are at the threshold of significance, and are equal to $2.36^{*}$. The values for $\mathrm{Cr}$ concentrations in liver are $28.22^{* *}$, in muscles $-4.88^{* *}$, and in gonads $-7.33^{* *}$.

The results obtained indicate that in gudgeons from both upper and lower parts of the Vardar, the liver is the end organ of accumulation of all the examined metals, especially $\mathrm{Pb}$ and $\mathrm{Cd}$ which in high concentrations accumulate in the gills too. Unlike the liver, muscles are tissues with very low contents of the examined

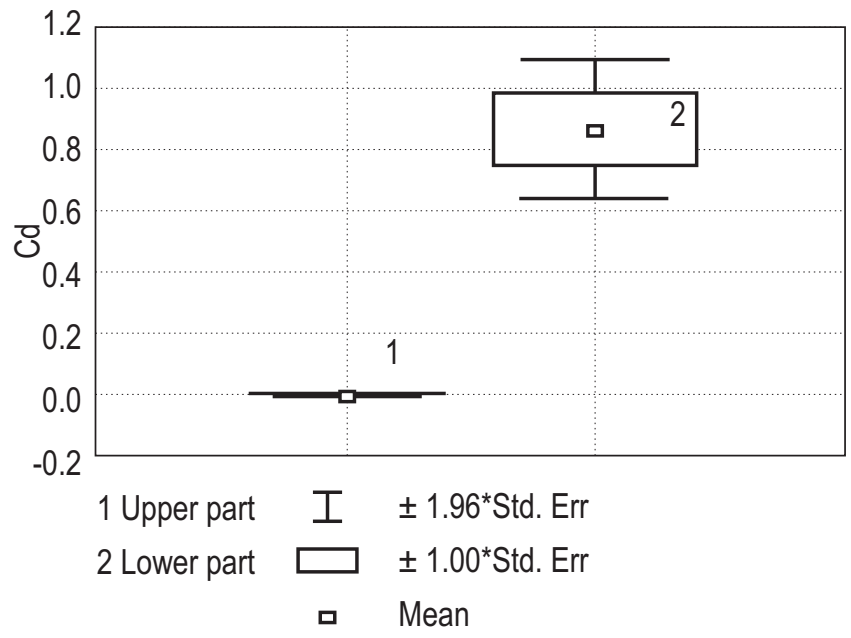

Figure 9. Cd concentrations in gills of Gobio gobio L. from the upper and the lower part of the Vardar River 


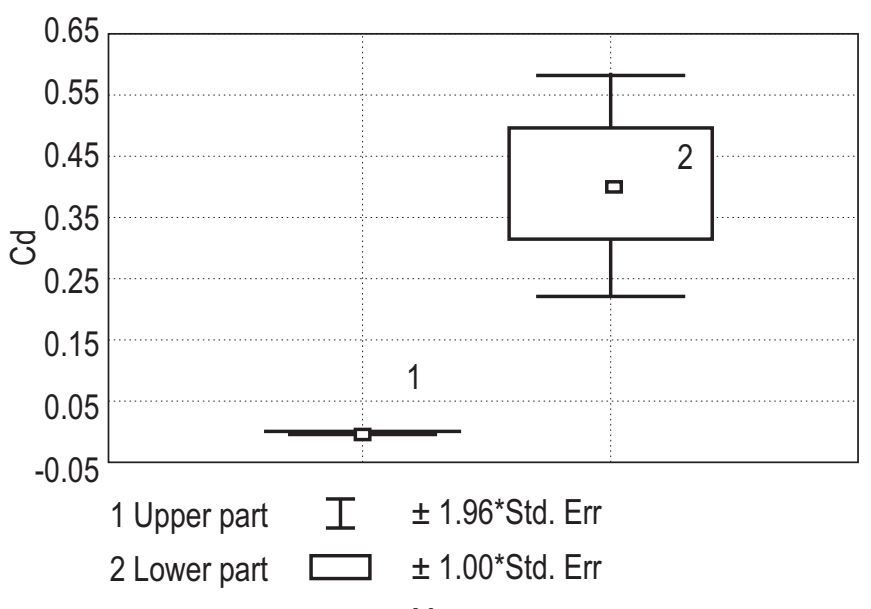

口 Mean

Figure 10. Cd concentrations in gonads of Gobio gobio L. from the upper and the lower part of the Vardar River

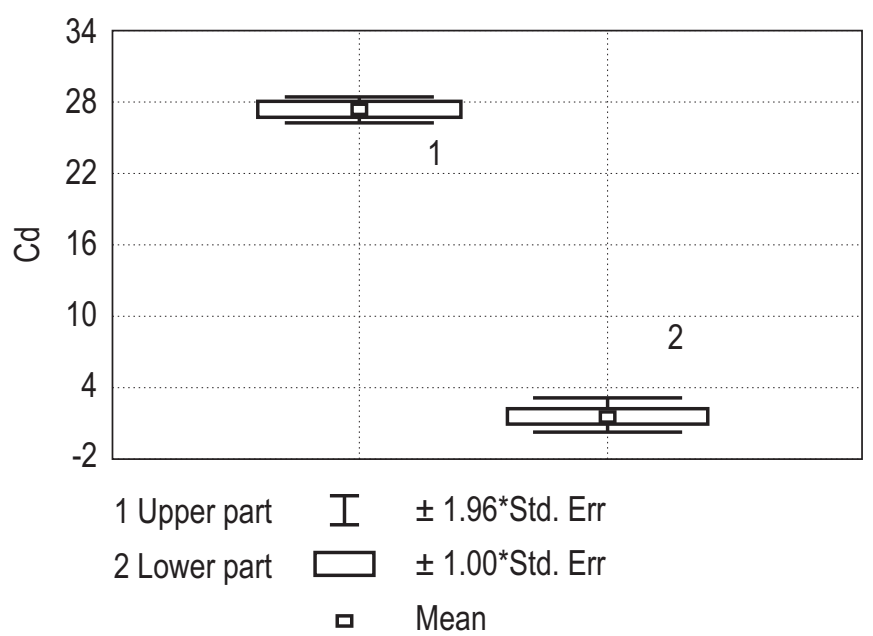

Figure 12. Cr concentrations in the liver of Gobio gobio L. from the upper and the lower part of the Vardar River

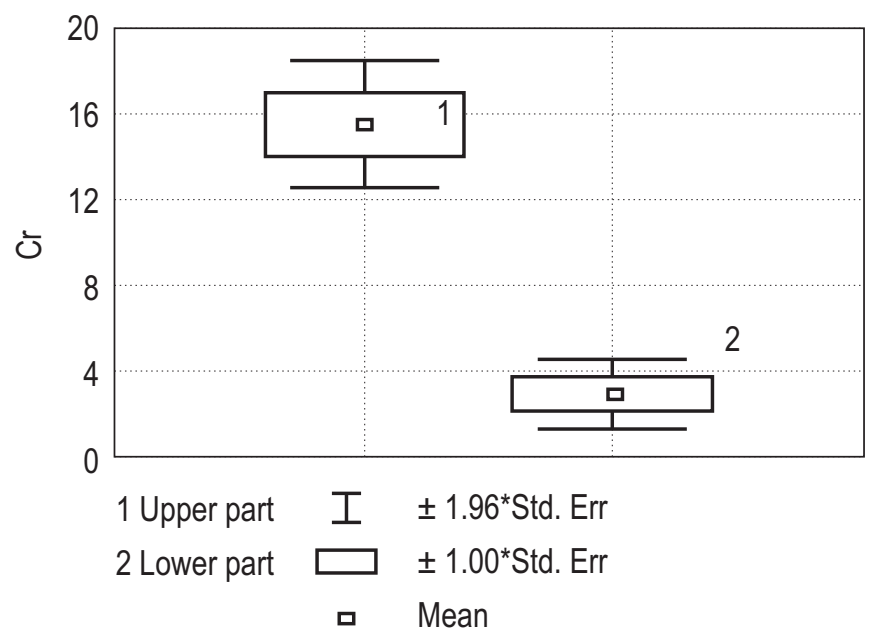

Figure 14. $\mathrm{Cr}$ concentrations in gonads of Gobio gobio L. from the upper and the lower part of the Vardar River metals, which is in line with the results of many authors who were studying the issue of their distribution in tissues. According to Wickund et al. (1988), cadmium accumulates in liver and in kidneys, and can be eliminated very slowly, while the zinc, present in the water, even increases its period of retention. The authors came to

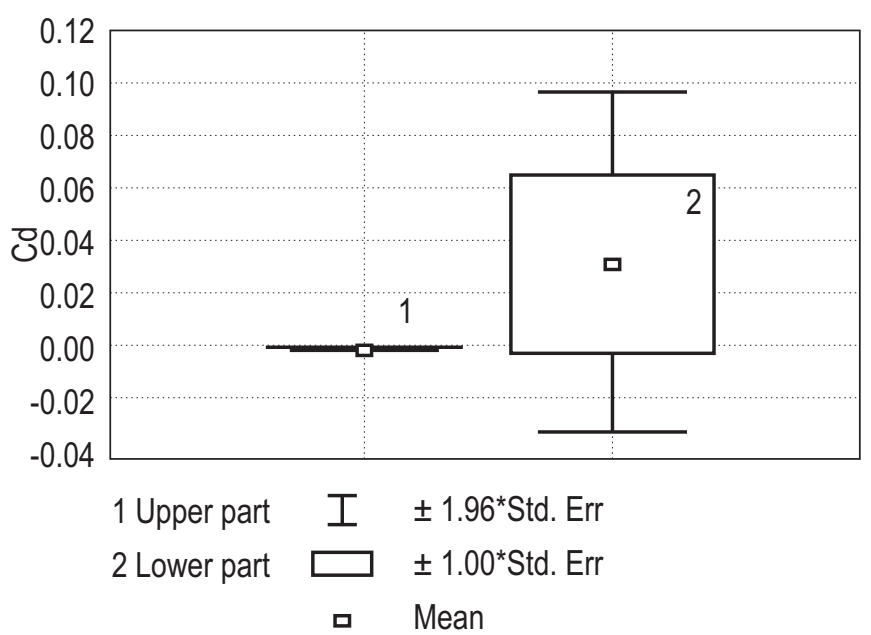

Figure 11. Cd concentrations in muscles of Gobio gobio L. from the upper and the lower part of the Vardar River

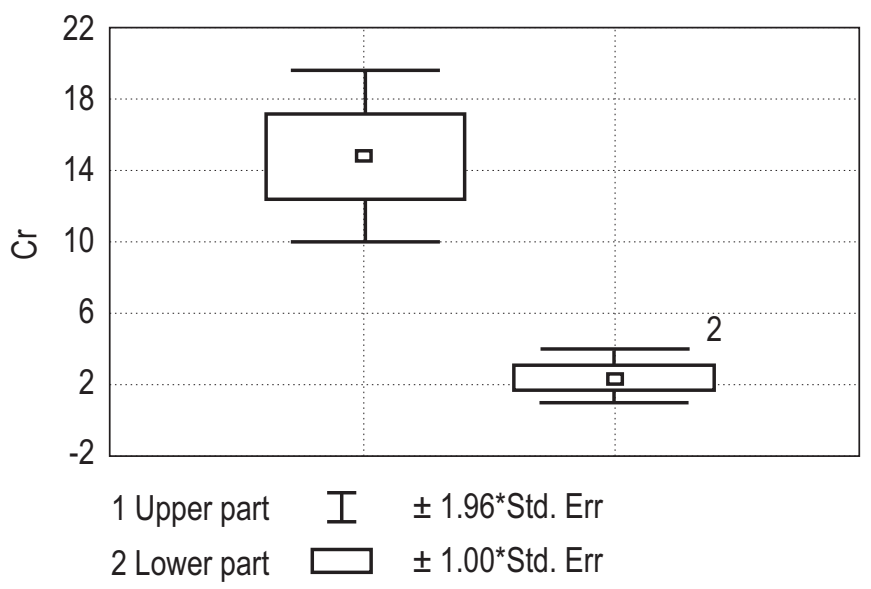

口 Mean

Figure 13. $\mathrm{Cr}$ concentrations in muscles of Gobio gobio L. from the upper and the lower part of the Vardar River

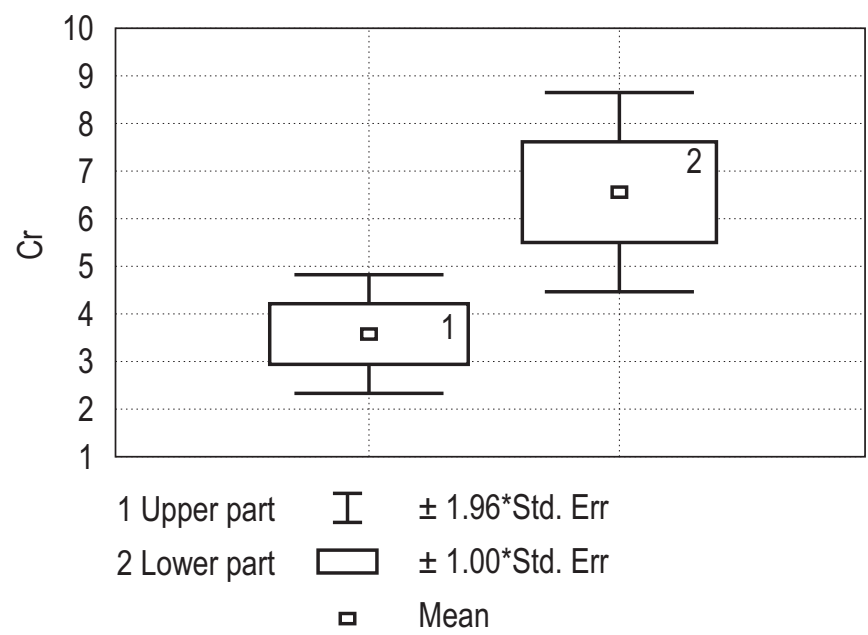

Figure 15. Cr concentrations in gills of Gobio gobio L. from the upper and the lower part of the Vardar River the conclusion that in waters loaded with zinc and cadmium, increased concentrations of zinc may lead to an increase of accumulation of cadmium in liver and in kidneys. One of the more interesting explanations for the significantly lower $\mathrm{Cd}$ and $\mathrm{Pb}$ accumulations in the muscles compared to those in kidneys and 
liver, is given by Allen-Gill and Martynov (1995). Although without any physiological function, the organisms retain both these metals through specific metal-bonding proteins. Namely, in kidneys and in liver the concentrations of metallotionein and lead-bonding proteins are significantly higher than in muscles, so it is logical the total $\mathrm{Pb}$ and $\mathrm{Cd}$ contents in these tissues to be higher.

Pujin et al. (1990) found that in Planktivora and Bentivora the muscles are the tissues with the lowest accumulations of $\mathrm{Zn}, \mathrm{Mn}, \mathrm{Fe}$, $\mathrm{Cu}, \mathrm{Cr}, \mathrm{Co}, \mathrm{Ni}, \mathrm{Pb}, \mathrm{Cd}, \mathrm{Al}$ and $\mathrm{Sr}$, while Maletin et al. (1996) spread this claim to all other trophic categories of fish. Đukić et al. (1998a, b), demonstrated that the accumulated amounts of all these metals are statistically quite low in muscles, and the highest in liver and kidneys. According to the investigations performed by Salanki et al. (1982), the concentrations of all the metals ( $\mathrm{Hg}, \mathrm{Cd}, \mathrm{Pb}, \mathrm{Zn}, \mathrm{Fe}, \mathrm{Cu}$ and $\mathrm{Mn}$ ) were the lowest in the muscles and the highest in the kidneys of both bentivore and piscivore species from Lake Balaton.

\section{Conclusion}

Ecotoxicological examinations were performed based on studying the presence of seven heavy metals (Fe, Cu, Zn, Mn, Cd, $\mathrm{Pb}$ and $\mathrm{Cr}$ ) in gudgeon's (Gobio gobio L.) organs. Increased concentrations of these hazardous substances, especially $\mathrm{Pb}$ and $\mathrm{Cd}$, in water and sediment from the lower part of the Vardar River, influenced higher accumulations of metals in liver, gills and gonads of Gobio gobio L. With the implementation of t-test, very significant differences in this respect were found between both surveyed parts of the river (the upper part and the lower part). It was found that the water of the Vardar River downstream the town of Veles is under permanent influence of the effluents which have very unfavourable impact on the wildlife of this ecosystem. These are the reasons for which it is necessary, based on the results obtained, to undertake steps for wastewater treatment, so the river would be able to recuperate and serve its purpose again. Simultaneously with the introduction to wastewater treatment plants, further monitoring of water quality is necessary if we want to achieve the goal of preservation and improvement of this hydroecosystem.

\section{References}

Antipa G, 1909. Fauna ichthyologica Romaniei. Academia Romana, Bucurst. Publishing.

American Public Health Association (APHA), 2005. Standard method for the Examination of Water and Wastewater. 16th ed. American Public Health Ass, p. 1266.

Dimovski A and Grupce R, 1971. The Ichthyofauna of Bregalnitsa River. Editions, IV, 7, Skopje (Mc).

Dimovski A and Grupce R, 1971a. Some problems of the Plasica fish (Alburnus) systematics in Macedonia. Acta Musei Macedonici Scientiarum Naturalium, XII, 4, 105 (Mc).

Dimovski A and Grupce R, 1971b. The morphological characteristic of the Belvica fish (Alburnus) in Dojran Lake and the Vardar River. Fragm. Balc. Mus. sword. Sc. Nat, VIII, 10, Skopje (Mc).

Dimovski A and Grupce R, 1972. Ichthyofauna of the Treska River. Acta Musei Macedonici Scientiarum Naturalium, XII, 9, 110, Skopje (Mc).

Doflein F, 1921. Macedonien. Jena.

Drecun $\boxplus$, 1956. Mugilidi (cipli) of Skadar Lake. Fisheries station,
Titograd, 1-4 (Sr).

Drecun $Ð$, 1957. Ichthtyofauna of Skadar Lake. Our agriculture, 3, 33-39(Sr).

Drecun $\boxplus, 1962$. Distribution and List of Freshwater Fish of Montenegro. Hydrobiologia Montenegrina, 2, 1-8 (Sr).

Đukić N, Maletin S, Seleši Đ and Miljanović B, 1991. Relationship between nutritive elements and Oligochaeta biomass in reservoirs of Pannonian basin - Yugoslavia. Fifth International Symposium on Aquatic Oligochaete Biology, Abstracts: 10, Tallin, Estonia.

Đukić N, Maletin S, Miljanović B and Marković Z, 1992. Water quality and distribution of the Oligochaet population in the Đetenica river. "Water Protection '92". Zbornik radova, 152-155, Subotica (Sr). Đukić N, Maletin S, Pujin, V, Ivanc A, Kojčić K and Miljanović B, 1993. Ecological estimation of water quality of the Tisa by physical and chemical biological parameters. Szegedi Ökológiai napok-24. Tiszakutató ankét, Szeged (Hungary), p. 8.

Đukić N, Maletin S, Pujin V, Ivanc A, Kojčić K and Miljanović B, 1994. Ecological assessment of water quality of the Tisza by physico-chemical and biological parameters. Tiscia, 28, 37-40.

Đukić N, Miljanović B, Maletin S, Ivanc A and Zhenjun S, 1996. Evaluation of Danube water quality in Yugoslavia according to the Oligochaeta community. Archiv für Hydrobiologie, Suppl. 113, Large Rivers 10, 1-4, Stuttgart, 523-527.

Đukić N, Maletin S, Teodorovic I, Tepavcevic D and Miljanovic B, 1997. Assessment of eutrophication level in Yugoslav part of Danube applying Fuzzy-Sets method. 7th International Symposium on Aquatic Oligochaetes. Abstracts, 10, Presque Isle, Maine, USA.

Đukić N, Maletin S, Teodorović I, Miljanović B and Vujošević Z, 1998b. The content of heavy metals in tissues and fish organs as an indicator of water quality in the hydro-system of the Danube-TisaDanube canal. "Water Protection '98", Proceedings, Kotor, pp. 283290 (Sr).

Foerstner V and Wittman GT, 1981. Metal pollution in the aquatic environment. Springer.

Hacker R, 1983. Rote Liste gefaehrdeter Fische Oesterreichs (Pisces). In: GEPP, J. (ed.). Rote Listen gefaehrdeter Tiere Oesterreichs, Wien, 67-68.

Ivanović B, 1973. Ichthyofauna of Skadar lake. Inst. biol. med. res. Montenegro, Titograd.

Janković D, 1965. Die geographisch-oekologisce Verbreitung der Fische in dem jugoslawischen Teil der Donau. Zborn. rad biol. inst., $8,27$.

Janković D, 1977. Current state of research of Serbia's Ichthyofauna and future research problems. Archives of Biological Sciences, 29, 7-12(Sr).

Janković D, 1978. Effects of anthropogenic factors on the zonal distribution of fishes in the Danube river system in Serbia (Yugoslavia). Verhandlungen der Internationalen Vereinigung für Theoretische und Angewandte Limnologie, 20, 2150-2153.

Janković D, 1979. Velika Morava's Ichthyofauna as limnosaprobe indicator. II Ecology Kongress of Jugoslavija, Zagreb, pp. 1477-1486 $(\mathrm{Sr})$.

Janković D, 1980. Crn Timok Ichthyiofauna drainage. Proceednings of SR Serbia's fauna. SR Srbije, Beograd, SANU, 1, 155-163 (Sr).

Janković D, Krpo J, Hegediš A, Maletin S and Kostić D, 1987. Die Struktur der Ichtyofauna im jugoslawischen Donauteil nach Untersuchungsfangen in 1986. 26. Arbeitstagung der IAD, Wiss. Kurzref., 261-165, Passau (De).

Janković D, Pujin V, Hegediš A, Maletin S, Krpo J, Lenhardt M, Kostić D, Anđelković D and Miljanović B, 1994. Community 
structure of the fish fauna in the Danube and its tributaries (in D. V. Janković and M. Ž. Jovičić eds.). The Danube in Yugoslavia contamination, protection and exploitation, Belgrade, pp. 137-148.

Janković DV and Jovičić MŽ, 1994. The Danube in Yugoslavija contamination, protection and exploitation, Belgrade.

Jorgensen LA and Pedersen B, 1994. Trace Metals in Fish used for Time Trend Analysis and as Environmental indicators. Marine Pollution Bulletin, 28, 235-243.

Jordanovski M and Naumovski T, 1998. Nitrogen and phosphorus load of the littoral belt of the Macedonian part of the Ohrid Lake. "Water Protection '98, Proceedings, Kotor (Sr).

Karaman S, 1962. Contribution to the knowledge of ichthyofauna of Macedonia. Biological gazette, 15, 187-192, Skopje (Sr).

Knezević B and Maric D, 1987. Ichthyofauna des Flussgebites Piva for und nach der Errichtung des Stausees "Piva", Montenegro. Ichthyolosis, 7, 1-4.

Maletin S, Đukić N and Kostić D, 1990. Analyse der Fischbestände in der Donau und in der Theiss in der Vojvodina und gegenseitiger Einfluss. Limnologische Berichte der 28. Tagung der IAD, Wissenschaftliche Kurzreferate, Varna, pp. 323-330 (Bg).

Maletin S, Đukić, N, Miljanović B, Marjanović P and Kositć D, 1991. The growth rate of trout (Salmo trutta $m$. Fario) as indicator of water productivity, potential sources of water supply. "Water Protection '91", Proceedings, Neum, pp. 338-344 (Sr).

Maletin S, Đukić N and Miljanović B, 1992. Heavy metals content in fish from Backwater Tisza (Biser island). Tiscia, 26, 57-60.

Water Protection '91, Proceedings, Igalo, 221-226 (Sr).

Maletin S, Đukić N, Ivanc A and Miljanović B, 1994. Beurteilung der Wassergüte des Flusses Crni Timok nach der Zusammensetzung der ichthyofauna. Limnologische Berichte Donau 1994, I, Wissenschaftliche Kurzreferate, 30. Arbeitstagung der IAD, Zuoz-Engadin (Schweiz), 401-404.

Maletin S, Đukić N, Ivanc A, Miljanović B and Pujin V, 1995. Heavy metal content of fish communities inhabiting the Yugoslav part of the Danube river system. First International Symposium "The Ecology of Large Rivers", Abstracts: 55, Krems/LowerAustria.

Maletin S, Đukić N, Obradović S, Ivanc A, Miljanović B, Pujin V and Zhenjun S, 1996. Heavy metal content of fish communities inhabiting the Yugoslav part of the Danube river system. Arch. Hydrobiol. Suppl. 113, Large Rivers 10, Stuttgart, 1-4, 535-540.

Maletin S, Đukić N, Miljanović B, Ivanc A and Pujin V, 1997. Composition of fish communities in the Danube River and its floodplain near Novi Sad. 32. Konferenz der Internationale Arbeitsgemeinschaft Donauforschung der S.I.L. Limnologische Berichte Donau 1997, Band I, Wissenschaftliche Referate, Wien, 353-357.

Maletin S and Đukić N, 1998. Structure of fish community in Yugoslav part of Danube. Inter. Symp. "Aquarom '98", Fisheries management in the Danube river basin. Extended abstracts: 66-67, Galati, Romania.

Nastova R, 2004. Study on the ichthyofauna of Vardar River in
Republic of Macedonia as an indicator of its contamination. Thesis for PhD, Trakia University, Stara Zagora, Bulgaria (Bg).

Nastova-Giorgioska R, Kostadinova G and Petkov G, 2006. Accumulation of heavy metals on the eco-trophological chain of Barbus Meridionalis Risso (Black Barbary) from the Vardar River in R. Macedonia. Ecology and Future, 9, 97-107.

Naumovski M, 1995. Fish in Macedonia, Systematic affiliation, biology and meaning $(\mathrm{Mc})$.

Petrovski N, Sidorovski M and Apostolski K, 1970. The state of fish populations in some tributaries of Vardar River. III Symposium "Contemporary ichthyological research", Kotor (Sr).

Petrović G, Janković D and Pujin V, 1987. Einige hydrochemische, hydrobiologische und ichthyologische Eigenschaften dre jugoslowischen Donaustrecke in mehrjaehrigem Zeitraum. Archiv Hydrobiology, 68, 257-267.

Pujin V, Đukić N, Maletin S, Obradović S and Kostić D, 1990. Content of heavy metals in some fish species in the Danube flowing through Vojvodina. Water Science and Technology, 22, 79-86.

Pujin V, Đukic N, Maletin S, Miljanovic B and Ivanc A, 1996. Changes of zoocenotic structure in the lower reach of the river Tisza. Tiscia, 30, 35-38.

Salanki J, Licsko I, Laszlo F, Balogh KV, Varanka A and Mastala Z, 1992. Changes in the concentration of heavy metals in the Zala Minor-Zala system (water, sediment, aquatic life). Water Science and Technology, 25, 173-180.

Steindachner F, 1892. Uber einige nene und seltene Fischartn aus der ichthyologischen sammlung des Natur Historischen Hofmusenms. Dendschr. derAkad. der Wisserschaft, Wien, Bd. LIX. Sytnik YuM, Arsan OM and Yewtushenko NYu, 1991. Der Schwermetall - Eiweiss - und Lipedengehalt in den Geweber enigen Fischarten der Donau. Limnol. Ber. 29. Tag. IAD, Kiew, 1778182.

Taler Z, 1954. Distribution and List of Freshwater Fish of Yugoslavia. Nature of the Serbian National Museum, 5-6, 425-455 (Sr).

Talevska M, 1998. Contents of some microelements in the reed belt of the Ohrid Lake. "Water Protection '98", Proceedings, Kotor (Sr).

Talevski T and Spirkovski Z, 1998. Anthropogenic impact on the fish population from Lake Ohrid. "Water Protection '98", Proceedings. Kotor, pp. 277-282(Sr).

Teodorović I, 1999. Fish settlement as bioindicator of metal hydrosystem loadings: possibility of water classification based on monitoring of micro-tobacco content in individual tissues and fish organs. Master thesis, Novi Sad (Sr).

Wachs B, 1990. Effects of Water Engineering Measures in the Structure of biocenosis and the Content of Noxious Pollutants in the Danube. Journal for Water and waste water Research, 23, 173-179.

Wachs B, 1991. Okobewertung der Schwermetallbelastung von Fliesgewassern. Münchner Beiträge zur Abwasser-, Fischerei- und Flußbiologie, 45, 295-336.

Yewtushenko NYu and Sytnik YuM, 1989. Heavy metals in fishes in the Danube. WPCRD, Novi Sad, pp. 498-502. 


\section{Genetics and Breeding}

Variation in the agronomic and morphological traits in spring barley

N. Dyulgerov, B. Dyulgerova

Study on the loss of accuracy of AC method for milk yield control in sheep

D. Dimov, P. Zhelyazkova, A. Vuchkov

Hordein polymorphism between spring barley cultivars by SDS-PAGE electrophoresis

N. Neykov, S. Doneva

\section{Nutrition and Physiology}

Comparative study of rapeseed, monofloral types and multifloral honey by some physico-chemical parameters

I. Zhelyazkova, S. Lazarov

Body condition score, nonesterified fatty acids and beta-hydroxybutyrate concentrations in goats with subclinical ketosis

V. Marutsova, R. Binev

\section{Production Systems}

Lucrative status of improved dual purpose cowpea (Vigna unguiculata L., Walp) in Damboa, Borno State, North-Eastern Nigeria

B.H. Gabdo

Study on the emptying time of grain harvester hoppers

K. Trendafilov, N. Delchev, B. Kolev, G. Tihanov

Length of the growing season and yield in Triticum monococcum L., in accordance with the growing conditions

S. Stamatov, E. Valchinova, G. Desheva, K. Uzundzhalieva, P. Chavdarov, T. Cholakov, B. Kyosev, R.

Ruseva, N. Velcheva

Productivity of durum wheat cultivar Predel at nitrogen-phosphorous fertilization

L. Plescuta

Effect of the herbicide treatment dose on the weed infestation in common winter wheat

Z. Petrova

Evaluation of some technological properties of Caucasian ram wool

D. Pamukova, G. Staykova, N. Stancheva, D. Panayotov 


\section{Agriculture and Environment}

Saved $\mathrm{CO}_{2}$ emissions by using renewable sources for hot water yield in Bulgarian dairy farms

R. Georgiev, R. Slavov, K. Peychev, D. Georgiev, S. Apostolov, J. Ellingsen, J. Tønnesen

Inventory of the legal base for reclamation of lands disturbed by open-cast mining in Bulgaria

M. Banov, V. Tzolova, I. Kirilov

Taxonomic composition of phytoplankton in Black Sea area in front of the Cape Galata (2008-2016)

D. Klisarova, D. Gerdzhikov

Biodiversity of the macrozoobenthos in some protected marine areas along Bulgarian Black Sea coast

E. Petrova, S. Stoykov

Heavy metals in organs of gudgeon (Gobio gobio L.) from Vardar River, R. Macedonia

R. Nastova, V. Kostov, I. Uslinovska

Product Quality and Safety

Mathematical methods for assessment and analysis of honey yield data for Bulgaria and the

N. Keranova

Carcass traits and meat quality of different slow growing and fast growing broiler chickens

M. Oblakova, N. Mincheva, P. Hristakieva, I. Ivanova, M. Lalev, Sv. Georgieva

Role and importance of the awareness for whey in dairy sector at an international level 


\section{Instruction for authors}

\section{Preparation of papers}

Papers shall be submitted at the editorial office typed on standard typing pages (A4, 30 lines per page, 62 characters per line). The editors recommend up to 15 pages for full research paper ( including abstract references, tables, figures and other appendices)

The manuscript should be structured as follows: Title, Names of authors and affiliation address, Abstract, List of keywords, Introduction, Material and methods, Results, Discussion, Conclusion, Acknowledgements (if any), References, Tables, Figures.

The title needs to be as concise and informative about the nature of research. It should be written with small letter /bold, 14/ without any abbreviations.

Names and affiliation of authors The names of the authors should be presented from the initials of first names followed by the family names. The complete address and name of the institution should be stated next. The affiliation of authors are designated by different signs. For the author who is going to be corresponding by the editorial board and readers, an E-mail address and telephone number should be presented as footnote on the first page. Corresponding author is indicated with *

Abstract should be not more than 350 words. It should be clearly stated what new findings have been made in the course of research. Abbreviations and references to authors are inadmissible in the summary. It should be understandable without having read the paper and should be in one paragraph.

Keywords: Up to maximum of 5 keywords should be selected not repeating the title but giving the essence of study.

The introduction must answer the following questions: What is known and what is new on the studied issue? What necessitated the research problem, described in the paper? What is your hypothesis and goal?

Material and methods: The objects of research, organization of experiments, chemical analyses, statistical and other methods and conditions applied for the experiments should be described in detail. A criterion of sufficient information is to be possible for others to repeat the experiment in order to verify results.

Results are presented in understandable tables and figures, accompanied by the statistical parameters needed for the evaluation. Data from tables and figures should not be repeated in the text. Tables should be as simple and as few as possible. Each table should have its own explanatory title and to be typed on a separate page. They should be outside the main body of the text and an indication should be given where it should be inserted.

Figures should be sharp with good contrast and rendition. Graphic materials should be preferred. Photographs to be appropriate for printing. Illustrations are supplied in colour as an exception after special agreement with the editorial board and possible payment of extra costs. The figures are to be each in a single file and their location should be given within the text.

Discussion: The objective of this section is to indicate the scientific significance of the study. By comparing the results and conclusions of other scientists the contribution of the study for expanding or modifying existing knowledge is pointed out clearly and convincingly to the reader. Conclusion: The most important consequences for the science and practice resulting from the conducted research should be summarized in a few sentences. The conclusions shouldn't be numbered and no new paragraphs be used. Contributions are the core of conclusions. References:

In the text, references should be cited as follows: single author: Sandberg (2002); two authors: Andersson and Georges (2004); more than two authors: Andersson et al.(2003). When several references are cited simultaneously, they should be ranked by chronological order e.g.: (Sandberg, 2002; Andersson et al., 2003; Andersson and Georges, 2004).

References are arranged alphabetically by the name of the first author. If an author is cited more than once, first his individual publications are given ranked by year, then come publications with one co-author, two co-authors, etc. The names of authors, article and journal titles in the Cyrillic or alphabet different from Latin, should be transliterated into Latin and article titles should be translated into English. The original language of articles and books translated into English is indicated in parenthesis after the bibliographic reference $($ Bulgarian $=\mathrm{Bg}$, Russian $=\mathrm{Ru}$, Serbian $=\mathrm{Sr}$, if in the Cyrillic, Mongolian =
Mo, Greek = Gr, Georgian = Geor., Japanese $=\mathrm{Ja}$, Chinese $=\mathrm{Ch}$, Arabic $=\mathrm{Ar}$, etc.)

The following order in the reference list is recommended:

Journal articles: Author(s) surname and initials, year. Title. Full title of the journal, volume, pages. Example:

Simm G, Lewis RM, Grundy B and Dingwall WS, 2002. Responses to selection for lean growth in sheep. Animal Science, 74, 39-50

Books: Author(s) surname and initials, year. Title. Edition, name of publisher, place of publication. Example:

Oldenbroek JK, 1999. Genebanks and the conservation of farm animal genetic resources, Second edition. DLO Institute for Animal Science and Health, Netherlands.

Book chapter or conference proceedings: Author(s) surname and initials, year. Title. In: Title of the book or of the proceedings followed by the editor(s), volume, pages. Name of publisher, place of publication. Example:

Mauff G, Pulverer G, Operkuch W, Hummel K and Hidden C, 1995. C3variants and diverse phenotypes of unconverted and converted C3. In: Provides of the Biological Fluids (ed. $\mathrm{H}$. Peters), vol. 22, 143-165, Pergamon Press. Oxford, UK.

Todorov N and Mitev J, 1995. Effect of level of feeding during dry period, and body condition score on reproductive performance in dairy cows, IX $X^{\text {th }}$ International Conference on Production Diseases in Farm Animals, September 11-14, Berlin, Germany.

Thesis:

Hristova D, 2013. Investigation on genetic diversity in local sheep breeds using DNA markers. Thesis for PhD, Trakia University, Stara Zagora, Bulgaria, (Bg).

The Editorial Board of the Journal is not responsible for incorrect quotes of reference sources and the relevant violations of copyrights.

\section{Animal welfare}

Studies performed on experimental animals should be carried out according to internationally recognized guidelines for animal welfare. That should be clearly described in the respective section "Material and methods". 


\section{AGRICULTURAL \\ SCIENCE AND TECHNOLOGY}

Volume 9, Number 4 December 2017
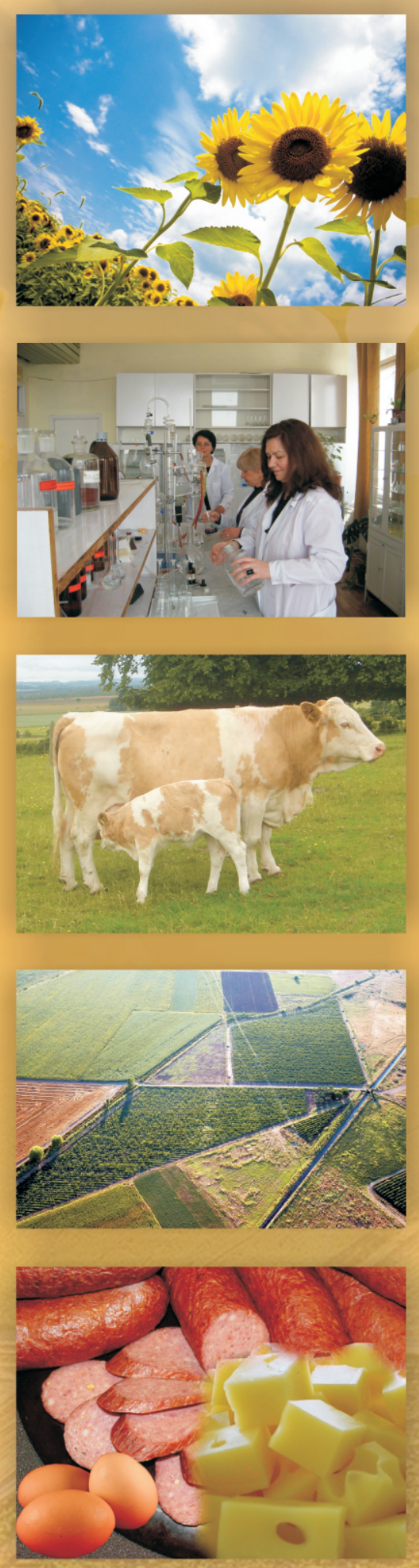

Journal web site: 